\title{
Cloning, Characterization, and Expression of a Novel GDP Dissociation Inhibitor Isoform from Skeletal Muscle
}

\author{
ASSIA SHISHEVA, ${ }^{1}$ THOMAS C. SÜDHOF, ${ }^{2}$ AND MICHAEL P. CZECH ${ }^{1 *}$ \\ Program in Molecular Medicine and Department of Biochemistry and Molecular Biology, \\ University of Massachusetts Medical Center, Worcester, Massachusetts 01605, ${ }^{1}$ \\ and Department of Molecular Genetics, Howard Hughes Medical Institute, \\ University of Texas Southwestern Medical Center, Dallas, Texas 75235-9050²
}

Received 9 December 1993/Returned for modification 12 January 1994/Accepted 8 February 1994

\begin{abstract}
Cellular mechanisms for controlling membrane trafficking appear to involve small GTP-binding proteins such as the Rab proteins. Rab function is regulated by GDP dissociation inhibitor (GDI), which releases Rab proteins from membranes and inhibits GDP dissociation. Here we report the isolation of a full-length cDNA encoding a novel GDI isoform of 445 amino acids (GDI-2) with a deduced molecular weight of 50,649 from mouse skeletal muscle. Full-length and partial cDNA clones encoding a previously reported GDI protein (GDI-1) were also isolated from cDNA libraries prepared from rat brain and mouse skeletal muscle, respectively. The degree of deduced amino acid sequence identity between mouse GDI-2 and our mouse GDI-1 cDNA clone is $86 \%$. Northern (RNA blot) analysis revealed that in human tissues, both GDI-1 and GDI-2 transcripts were abundant in brain, skeletal muscle, and pancreas but were weakly expressed in heart and liver. GDI-1 mRNA was expressed in kidney, whereas GDI-2 was almost absent, while in lung the relative amounts of these mRNA species were reversed. Specific antibodies against mouse GDI-1 and GDI-2 based on unique peptide sequences in the proteins were raised. Differentiation of 3T3-L1 fibroblasts into highly insulin-responsive adipocytes was accompanied by large increases in both mRNA and protein levels of GDI-1 and GDI-2. GDI-1 and GDI-2 expressed as glutathione $S$-transferase fusion proteins were both able to solubilize the membrane-bound forms of Rab4 and Rab5 in a GDP/GTP-dependent manner. Taken together, these data demonstrate that the protein products of at least two genes regulate the membrane dynamics of Rab proteins in mice.
\end{abstract}

Over the past several years, significant evidence implicating p2 $1^{\text {ras }}$-like small GTP-binding proteins in the mechanisms driving membrane-trafficking pathways has been obtained (for reviews, see references 1,23 , and 36). In particular, the subfamily of Rab proteins appears to participate in vesicle targeting or fusion events. The cycling of these proteins between the inactive (GDP bound) and active (GTP bound) states is believed to catalyze docking to specific target membranes. Thus, in the sec 4 mutant yeast strain, the fusion of secretory vesicles to the plasma membranes is perturbed (27); antibodies against Rab1 and its yeast homolog, YPT1, block transport between the endoplasmic reticulum and Golgi complex $(24,26,31)$; anti-Rab5 antibodies block early endosome fusion (13); and antisense oligonucleotides against Rab3B inhibit $\mathrm{Ca}^{2+}$-dependent exocytosis (18).

Three types of factors that regulate the interactions of guanine nucleotides with the various $\mathrm{Rab}$ proteins have been described: GTPase activating proteins, found for $\mathrm{p} 25^{\text {rah } 3 A}$ (4) and YPT1 (3), accelerate their intrinsic GTPase activity and presumably catalyze their deactivation in vivo; GDP dissociation stimulators increase release of GDP from p25 rab3A $(5)$ and the yeast counterparts SEC4 and YPT1 (20), allowing their reactivation by binding to GTP; and GDP dissociation inhibitor (GDI) inhibits the release of GDP from Rab proteins and plays a role in the recycling of the Rab proteins from target to donor membrane vesicles $(30,37)$. These regulatory proteins, together with others now being identified, such as rabphilin

* Corresponding author. Mailing address: Program in Molecular Medicine, University of Massachusetts Medical Center, 373 Plantation St., Worcester, MA 01605. Phone: (508) 856-2254. Fax: (508) 8564289 .
(32), are thought to compose a complex cellular system for coordinating membrane trafficking.

Two GDI proteins have been identified for members of the Rab subfamily $(30,37)$. One interacts with almost all of the Rab proteins tested $(29,34,38)$, while the other interacts with Rab11 (also designated 24K [37]) but not Rab3A (also designated smg p25A [30]). The former GDI cDNA has been cloned from bovine brain, and its mRNA has been detected in all tissues studied (19). It is also present in secretory cells with both regulated and constitutive secretion pathways (22), where it is found predominantly in the cytosol complexed with small GTP-binding proteins $(25,34)$. Initial attempts to identify a yeast counterpart of GDI with the bovine cDNA as a probe under low-stringency conditions have not yet been successful (29). These findings indicate that GDI proteins are important modulators of GDP/GTP exchange reactions involving Rab proteins and are potential candidates for regulation by cellular signaling mechanisms.

Insulin stimulation of glucose uptake in fat and skeletal muscle involves the redistribution of a major glucose transporter isoform, GLUT4, from trans-Golgi or endosomal tubulovesicular organelles to the plasma membrane (for a review, see reference 9). Recent studies indicate that insulin modulates both the exocytosis and endocytosis pathways of GLUT4 protein trafficking in fat cells $(8,16,40)$. Several considerations suggest that Rab proteins may also be involved in the membrane movements of GLUT4 transporter proteins. The expression of a novel Rab protein (Rab3D) appears to be associated with differentiation of 3T3-L1 fibroblasts to insulin-responsive cells (2). Furthermore, the redistribution of Rab4 protein from fat cell low-density microsomes to the cytosol in response to insulin has recently been observed (7). 
To investigate the presence of GDI proteins in insulinsensitive tissues, we screened a mouse skeletal muscle cDNA library for cDNA species encoding GDI proteins. We have isolated a full-length cDNA encoding a novel GDI isoform (mGDI-2) as well as a cDNA encoding the nearly complete amino acid sequence of the GDI previously cloned from bovine brain (mGDI-1). The mRNA and protein levels of both GDI species were found to increase markedly upon differentiation of 3T3-L1 fibroblasts and L6 myoblasts to insulinsensitive adipocytes and myocytes, respectively. Moreover, the recombinant GDI-1 and GDI-2 proteins were able to modulate the membrane association of Rab4 and Rab5 proteins. These findings raise the possibility that GDI proteins may be involved in insulin-regulated membrane recycling of glucose transporters.

\section{MATERIALS AND METHODS}

Cell culture. L6 rat myoblasts (a gift from J. Lawrence, Washington University, St. Louis, Mo.) were grown to confluence (150-mm plate) in Dulbecco's modified Eagle's medium (DMEM) containing $10 \%$ calf serum, $50 \mathrm{U}$ of penicillin per $\mathrm{ml}$, and $50 \mu \mathrm{g}$ of streptomycin sulfate per $\mathrm{ml}$. The differentiation of L6 myoblasts was initiated by replacing the calf serum from the above medium with $5 \%$ fetal horse serum. The composition of the medium was kept the same until the end of the differentiation program, with medium changes every 2 to 3 days. Mouse 3T3-L1 fibroblasts were differentiated into adipocytes as described previously (14). Briefly, fibroblasts were grown to confluence $(150-\mathrm{mm}$ plate) in DMEM containing $10 \%$ calf serum, penicillin $(50 \mathrm{U} / \mathrm{ml})$, and streptomycin sulfate $(50$ $\mu \mathrm{g} / \mathrm{ml})$. Differentiation was induced with DMEM supplemented with $10 \%$ fetal bovine serum, penicillin $(50 \mathrm{U} / \mathrm{ml})$, streptomycin sulfate $(50 \mu \mathrm{g} / \mathrm{ml})$, insulin $(5 \mu \mathrm{g} / \mathrm{ml}), 0.25 \mu \mathrm{M}$ dexamethasone, and $0.5 \mathrm{mM}$ 3-isobutyl-1-methylxanthine. On the second day, the medium was replaced with DMEM containing all but the last two of the above components. Thereafter, the cells were maintained in DMEM containing $10 \%$ fetal bovine serum and the antibiotics, with medium changes every 2 to 3 days. COS-7 cells were grown (100-mm plate) in DMEM containing $10 \%$ fetal bovine serum and the above antibiotics.

rGDI cloning. The coding region of rat GDI (rGDI) was cloned by PCR from single-stranded cDNA from rat brain. PCR was performed with oligonucleotides with the sequences CTGACCATGGACGAGGA $(\mathrm{A}, \mathrm{G}) \mathrm{TA}(\mathrm{C}, \mathrm{T}) \mathrm{A}$ and $\mathrm{CGCG}$ GATCCTACTGGTCAGCTTCCCC(G,A)AA(G,A,C)AC (parentheses indicate redundant positions) as described before (39). The PCR product was cloned into mammalian and bacterial expression vectors by using the flanking restriction sites engineered into the oligonucleotides used for the PCRs. The cDNA insert was fully sequenced after subcloning into M13 vectors by the dideoxy nucleotide chain termination method (28) with fluorescently labeled primers and Taq DNA polymerase; sequencing reaction mixes were analyzed on an ABI 370A DNA sequencer.

Screening of the mouse skeletal muscle cDNA library. A mouse skeletal muscle cDNA library constructed in the $\lambda$ gt 10 bacteriophage vector (Clontech Laboratories) was screened with the full-length rat brain cDNA for GDI described above. The procedure was essentially that of Strauss (35). A total of 800,000 PFU were plated on the C600 Hfl strain of Escherichia coli as the host (Clontech). The plaques were transferred onto nitrocellulose filters (Millipore), alkali denatured, and fixed for $2 \mathrm{~h}$ at $80^{\circ} \mathrm{C}$ in a vacuum oven. The cDNA probe was ${ }^{32} \mathrm{P}$ labeled by random priming (10). The filters were hybridized in $6 \times \mathrm{SSC}(1 \times \mathrm{SSC}$ is $150 \mathrm{mM} \mathrm{NaCl}, 15 \mathrm{mM}$ trisodium citrate $\left.\cdot 2 \mathrm{H}_{2} \mathrm{O}[\mathrm{pH} 7.0]\right)-5 \times$ Denhardt's solution $(1 \times$ Denhardt's solution is $0.02 \%$ each bovine serum albumin, polyvinylpyrrolidone, and Ficoll)-50\% formamide-10 mM EDTA$0.5 \%$ sodium dodecyl sulfate (SDS) $-25 \mu \mathrm{g}$ of denatured salmon sperm DNA per $\mathrm{ml}$ at $42^{\circ} \mathrm{C}$ for $16 \mathrm{~h}$ and then washed five times for $10 \mathrm{~min}$ each with $1 \times \mathrm{SSC}-0.1 \% \mathrm{SDS}$ at $50^{\circ} \mathrm{C}$. The selected cDNA clones were subcloned into the EcoRI site of pBluescript $\mathrm{SK}^{+}$vector (Stratagene). The larger inserts were further restricted with BamHI, PstI, or HindIII (Promega) and again subcloned into the respective polylinker sites of pBluescript for sequencing.

cDNA sequences were determined at least three times on two strands by the dideoxynucleotide method (28) with Sequenase version 2.0 (United States Biochemical Corp.) and SK, $\mathrm{KS}, \mathrm{T} 3$, and cDNA-specific primers. DNA and protein sequence comparisons were carried out with CLUSTAL V software (15).

RNA isolation. Total RNA was extracted from L6 or 3T3-L1 cells on various days of the differentiation programs by the guanidinium thiocyanate method (6) with TRI (RNA/DNA/ protein isolation) reagent (Molecular Research Center, Inc.). Polyadenylated [poly $(\mathrm{A})^{+}$] RNA was selected by oligo(dT)cellulose chromatography with commercial columns and the manufacturer's protocol (Molecular Research Center, Inc.). $\operatorname{Poly}(\mathrm{A})^{+}$RNA was dissolved in water, quantified by measuring the $A_{260}$, and subjected to electrophoresis on agarose gels followed by ethidium bromide staining for analysis of its integrity.

Northern (RNA blot) analysis. RNA transcript levels were measured by Northern blot analysis. Poly $(A)^{+}$RNA $(3 \mu \mathrm{g})$ was fractionated on a formaldehyde-1\% agarose gel and then blotted and fixed onto a GeneScreen Plus nylon membrane (DuPont NEN Products). The Northern blot of poly $(\mathrm{A})^{+}$ RNA from different human tissues was obtained from Clontech. The blots were hybridized with the GDI-1 or GDI-2 cDNA probe $\left({ }^{32} \mathrm{P}\right.$ labeled to $10^{9} \mathrm{cpm} / \mu \mathrm{g}$ by random priming) for $16 \mathrm{~h}$ at $42^{\circ} \mathrm{C}$ in $5 \times \operatorname{SSPE}(1 \times$ SSPE is $150 \mathrm{mM} \mathrm{NaCl}, 10$ $\mathrm{mM} \mathrm{NaH} \mathrm{PO}_{4} \cdot 1 \mathrm{H}_{2} \mathrm{O}, 1 \mathrm{mM}$ disodium EDTA [pH 7.4])-50\% formamide- $10 \times$ Denhardt's solution-2\% SDS-100 $\mu \mathrm{g}$ of denatured salmon sperm DNA per ml. Blots were washed at a final stringency of $0.1 \times \mathrm{SSC}-0.1 \%$ SDS at $67^{\circ} \mathrm{C}$ for $30 \mathrm{~min}$. The amounts of poly $(\mathrm{A})^{+}$RNA on the blots were controlled by hybridization with labeled $\beta$-actin cDNA (kindly provided by David Hartley, Program in Molecular Medicine, University of Massachusetts Medical Center, Worcester). Transcript levels were quantitated by scanning the autoradiograms with an enhanced laser densitometer (Ultrascan XL; LKB). Two exposures of each blot were quantified to ensure that the exposures were within the linear range of the film.

Production of GST-GDI-1 and GST-GDI-2 fusion proteins. The entire mGDI-2 protein was expressed as a glutathione $S$-transferase (GST) fusion protein by using the pGEX-1 vector (Amrad). In order to delete the flanking nucleotide sequence in the $5^{\prime}$ noncoding region of mGDI-2, a DNA fragment was synthesized by PCR with the cloned isoform as a template and oligonucleotides that contained an appropriate restriction site $370 \mathrm{bp}$ from the natural ATG start codon (5' primer, CCGGAATTCATGAATGAGGAG; 3' primer, CTG CTTCAGTGGAAGGA). The amplified DNA fragment was isolated, digested with EcoRI and NcoI, and, together with the NcoI-EcoRI fragment of mGDI-2 cDNA, was cloned into the EcoRI site of pGEX-1 in frame with the GST gene.

To generate the GST-GDI-1 fusion protein, a 10-mer double-stranded oligonucleotide (CATGGGATCC) carrying Bam HI and tailed with NcoI restriction sites was inserted in frame with the initial Met codon into an NcoI digest of 
pET8c-rGDI-1 cDNA. The BamHI cDNA fragment of the new vector encoding full-length rGDI-1 cDNA (1.4 kbp) was subcloned into the BamHI site of pGEX-1 in frame with the GST gene.

E. coli XA-90 was used for transformations. The new vectors, pGEX-mGDI-2 and pGEX-rGDI-1, were confirmed by sequencing. Transformed cells were grown and treated with $0.5 \mathrm{mM}$ isopropyl-1-thio- $\beta$-D-galactopyranoside for $4 \mathrm{~h}$. The cells were lysed in buffer containing $50 \mathrm{mM}$ HEPES $(\mathrm{N}-2$ hydroxyethylpiperazine- $N^{\prime}$-2-ethanesulfonic acid, $\mathrm{pH} 7.4$ ), 150 $\mathrm{mM} \mathrm{NaCl}, 5 \mathrm{mM}$ EDTA, $1 \%$ Triton X-100, $1 \mathrm{mM}$ phenylmethylsulfonyl fluoride (PMSF), $1 \mathrm{mg}$ of bacitracin per $\mathrm{ml}$, $5 \mu \mathrm{g}$ of aprotinin per $\mathrm{ml}$, and $5 \mu \mathrm{g}$ of leupeptin per $\mathrm{ml}$ by sonication for $2 \mathrm{~min}$ and centrifuged at $12,000 \times g$ for $25 \mathrm{~min}$. The supernatant was applied to glutathione-agarose beads (Sigma) that were extensively washed with $50 \mathrm{mM}$ Tris- $\mathrm{HCl}$ (pH 8.0) containing $0.05 \%$ Triton X-100. The GST-GDI-1 and GST-GDI-2 fusion proteins were eluted with the same buffer containing $5 \mathrm{mM}$ glutathione, which was then removed by repeating ultrafiltration in a Centricon 30 microconcentration unit (Amicon).

Epitope tagging and transient-expression assay. The fulllength rGDI-1 cDNA (1.4 kbp) was tagged in the $\mathrm{NH}_{2}$ terminus with a nine-amino-acid epitope, YPYDVPDYA, derived from influenza virus hemagglutinin (HA) (11). Oligonucleotides encoding the sequence detailed above after the initial Met tailed with convenient restriction sites on the ends $\left(5^{\prime}, X b a \mathrm{I} ; 3^{\prime}, \mathrm{NcoI}\right)$ were used. The double-stranded oligonucleotide was inserted into an $\mathrm{XbaI}-\mathrm{NcoI}$ digest of pET8crGDI-1 cDNA. The HA-GDI-1 cDNA fragment was subcloned into mammalian expression vector pCMV5 (cloning sites, $X b a \mathrm{I}$ and $B a m \mathrm{HI}$ ). The new vector, HA-rGDI-1 pCMV5, was confirmed by sequencing. The full-length mGDI-2 was tagged in the $\mathrm{NH}_{2}$ terminus with an 11-amino-acid epitope, EQKLISEEDLN, derived from the human c-myc proto-oncogene product (21). Oligonucleotides encoding the sequence detailed above after the initial Met tailed with convenient restriction sites (PstI and EcoRI) were used. The doublestranded oligonucleotide was ligated into a PstI-EcoRI digest of pBluescript-mGDI-2 cDNA that lacked the 5' noncoding region of cloned mGDI-2 (deleted by PCR as described above). The vector pBluescript-c-myc-mGDI-2 was confirmed by sequence analysis. The PstI-SalI c-myc-mGDI-2 cDNA fragment was further subcloned into the PstI-SalI digest of pCMV5.

COS-7 cells were seeded at 750,000 cells per $100-\mathrm{mm}$ plate, and transfection of HA epitope-tagged rGDI-1 and c-Myc epitope-tagged mGDI- 2 cDNAs was performed by the calcium phosphate precipitation method as described before (12). Cell lysates were analyzed by Western blotting (immunoblotting) 48 $\mathrm{h}$ later.

In vitro dissociation assay. COS-7 cells (serum starved for 5 $\mathrm{h}$ before the experiment) were washed twice before homogenization at $4^{\circ} \mathrm{C}$ in $20 \mathrm{mM}$ HEPES buffer ( $\left.\mathrm{pH} 7.4\right)$ containing 1 mM EDTA, $250 \mathrm{mM}$ sucrose, $1 \mathrm{mM}$ PMSF, $5 \mu \mathrm{g}$ of leupeptin per $\mathrm{ml}$, and $5 \mu \mathrm{g}$ of aprotinin per $\mathrm{ml}$. Equal amounts $(120 \mu \mathrm{g}$ of protein) of postnuclear membrane fraction (two sequential centrifugations [ $10 \mathrm{~min}$ at $800 \times g$ and $15 \mathrm{~min}$ at $200,000 \times g$ ] in a Beckman TL-100 Ultracentrifuge) were incubated for 30 min at $30^{\circ} \mathrm{C}$ in the presence or absence of the GST-GDI-1 or GST-GDI-2 fusion protein or GST alone (each at $1 \mu \mathrm{M}$ ) in a reaction buffer consisting of $50 \mathrm{mM}$ HEPES-KOH ( $\mathrm{pH} 7.6$ ), 5 $\mathrm{mM} \mathrm{MgCl}, 1 \mathrm{mM}$ dithiothreitol, $1 \mathrm{mM}$ PMSF, $5 \mu \mathrm{g}$ of aprotinin per $\mathrm{ml}, 5 \mu \mathrm{g}$ of leupeptin per $\mathrm{ml}$, and $1 \mu \mathrm{g}$ of pepstatin per $\mathrm{ml}$. Where indicated, the membranes were preincubated for $45 \mathrm{~min}$ at $30^{\circ} \mathrm{C}$ with GTP $\gamma \mathrm{S}$ or GDP (each at
$1 \mathrm{mM})$. The reaction mixtures were pelleted for $10 \mathrm{~min}$ at $200,000 \times g$, and the membranes and the soluble fractions were analyzed for Rab4 and Rab5 content by fractionation by SDS-polyacrylamide gel electrophoresis (PAGE; 10.5\% polyacrylamide gel) and Western blotting with affinity-purified anti-Rab4 antibodies (generously provided by Ira Mellman) and affinity-purified monoclonal anti-Rab5 antibodies (generously provided by Marino Zerial) under the conditions described below.

Cell lysis, cell fractionation, and immunoblotting. Transfected COS-7 cells were washed twice with ice-cold phosphatebuffered saline (PBS) prior to lysis with $1 \mathrm{ml}$ of lysis buffer (50 mM HEPES [pH 7.5], $150 \mathrm{mM} \mathrm{NaCl}, 1 \mathrm{mM}$ PMSF, $0.1 \%$ SDS, $0.5 \%$ sodium deoxycholate, $1 \%$ Nonidet P-40). Lysates were incubated for $5 \mathrm{~min}$ on ice and clarified by centrifugation for 15 $\min$ at $16,000 \times g$. Equal amounts of total protein, as measured by the bicinchoninic acid protein assay reagent (Pierce), were fractionated by SDS-PAGE, transferred to nitrocellulose, and blotted with anti-c-Myc monoclonal antibody, anti-HA monoclonal antibody, anti-mGDI-1 peptide antiserum, or anti-mGDI-2 peptide antiserum under conditions described elsewhere (33). Antibodies were detected by enhanced chemiluminescence (Amersham).

For studying the relative amounts of mGDI-1 and mGDI-2 proteins in 3T3-L1 mouse fibroblasts and differentiated adipocytes, the cells were first homogenized at $4^{\circ} \mathrm{C}$ in $20 \mathrm{mM}$ HEPES buffer (pH 7.4) containing $1 \mathrm{mM}$ EDTA, $250 \mathrm{mM}$ sucrose, $1 \mathrm{mM}$ PMSF, $5 \mu \mathrm{g}$ of leupeptin per $\mathrm{ml}$, and $5 \mu \mathrm{g}$ of aprotinin per $\mathrm{ml}$. Cytosol fractions were obtained as described above and analyzed by immunoblotting.

Antibodies. Rabbit polyclonal anti-GDI-1 and anti-GDI-2 antibodies are directed against an mGDI-1 peptide (amino acids 431 to 447 ) and an mGDI-2 peptide (amino acids 386 to $404)$, respectively. The peptides were coupled via an aminoterminal tyrosine to keyhole limpet hemocyanin. Antisera were used at a dilution of 1:14,000 for immunoblotting. Mouse monoclonal antibody 12CA5 (BAbCO), reactive with the influenza virus HA epitope YPYDVPDYA (11), was used to detect epitope-tagged HA-rGDI-1. Mouse monoclonal antibody ATCC 1729, reactive with the epitope EQKLISEEDLN (21) derived from the c-myc proto-oncogene product, was used to detect epitope-tagged c-Myc-mGDI-2.

\section{RESULTS AND DISCUSSION}

Isolation and nucleotide sequence analysis of mGDI-1 and mGDI-2 cDNAs. To isolate cDNA clones encoding GDI proteins expressed in muscle, we screened a mouse skeletal muscle cDNA library with a probe corresponding to the entire coding region of rat brain GDI under conditions of moderate stringency. Seven recombinant plaques were found to be strongly positive. One clone (pG4) exhibited weak hybridization to this probe, suggesting that it may have been derived from a new GDI-related gene. All eight recombinant plaques were purified, and their EcoRI inserts (ranging in size from 1.3 to $3.7 \mathrm{kbp}$ ) were subcloned into pBluescript vectors. The resulting plasmids were sequenced either directly or after further appropriate restrictions and subcloning into pBluescript. Figure 1 shows the nucleotide sequence of the pG4 clone, designated mGDI-2. This mGDI-2 cDNA is about 2.4 $\mathrm{kbp}$ long and contains an open reading frame encoding 445 amino acids flanked by approximately 500 nucleotides on the $5^{\prime}$ as well as the $3^{\prime}$ sides. The predicted ATG initiation codon conforms well with the canonical sequence for the mammalian translation initiation start site proposed by Kozak (17). Moreover, the presence of an in-frame terminator upstream of this 


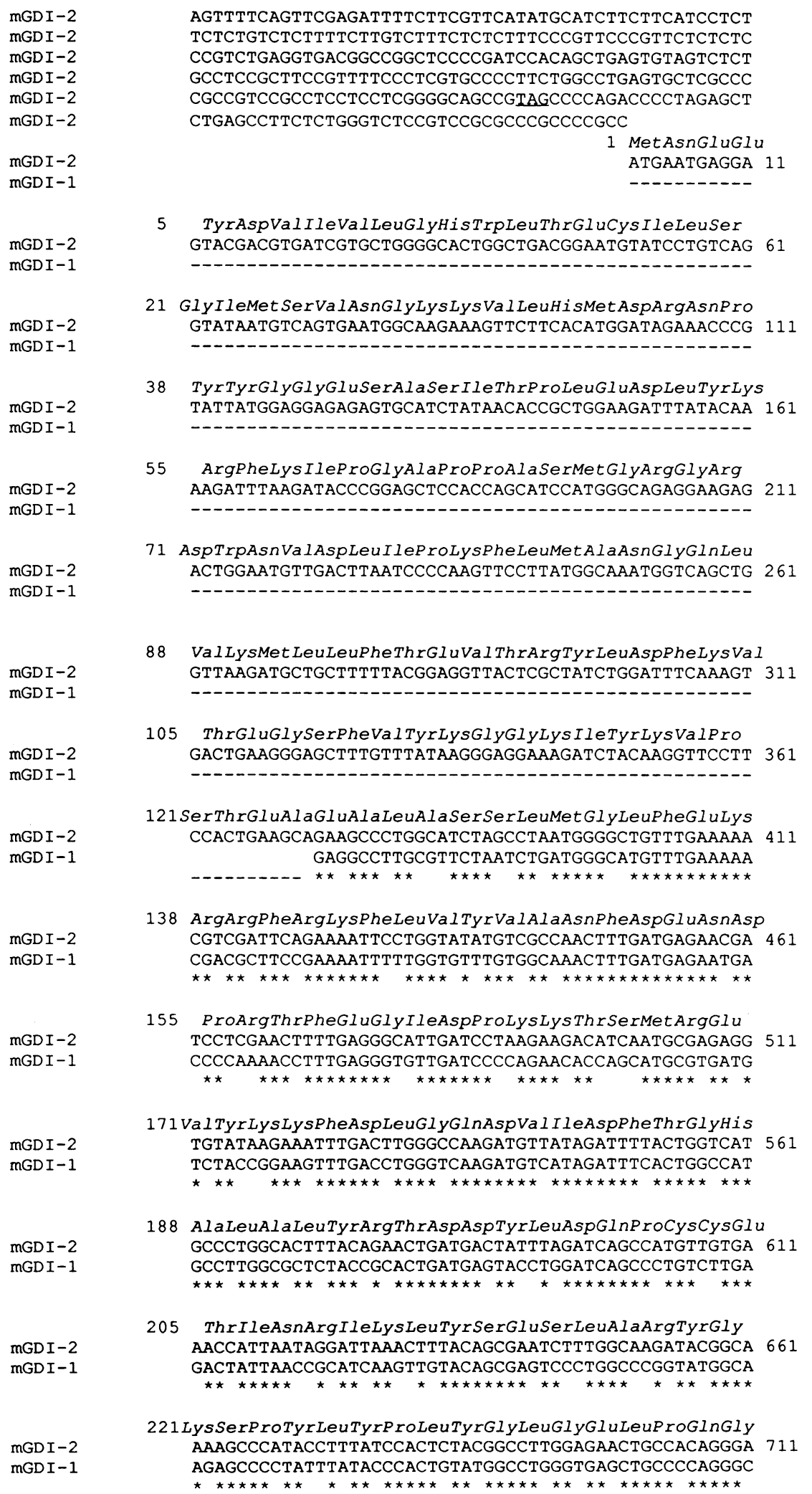

FIG. 1. Nucleotide sequences of the cDNA clones for mGDI-1 and mGDI-2 and deduced amino acid sequence of mGDI-2. Identical nucleotides are denoted by stars. The termination codon of mGDI-2 is marked ( $\left.{ }^{* * *}\right)$, and the in-frame TAG upstream of the initiating Met codon is underlined. Dashes denote unknown nucleotides of mGDI-1. 
MGDI -2 mGDI-1

mGDI -2 mGD I-1

mGDI - 2 MGDI-1

mGDI -2 mGD I-1

mGD I - 2 mGD I - 1

mGDI-2 mGD I - 1

MGD I-2 mGD I-1

mGDI -2 mGDI - 1

mGDI -2 MGDI -1

MGDI -2 mGD I - 1

MGDI -2 mGDI -1

mGDI -2 mGDI-1

MGDI -2 mGDI-1

mGDI -2 MGDI-1 MGDI -2 mGD I-1
238 PheAlaArgLeuSerAlaIleTyrGlyGlyThrTyrMet LeuAsnLysPro TTTGCACGGCTAAGTGCTATATATGGAGGTACCTACATGCTGAATAAACC 761

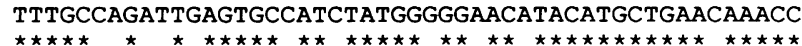

255 IleGluGluIleIleMetGInAsnGIyLysValIleGlyValLysSer AATTGAAGAAATCATTATGCAAAATGGAAAGGTGATTGGTGTAAAATCTG 811 AGTGGATGACATCATCATGGAAAATGGCAAGGTGGTGGGTGTCAAATCTG

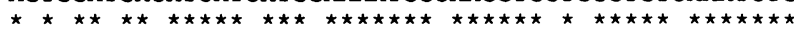

271GIuGIyGIUIleAlaArgCysLysGInLeuIleCysAspProSerTyrVal AAGGAGAGATTGCTCGCTGTAAGCAGCTCATCTGCGATCCCAGCTATGTG 861 AGGGAGAGGTGGCCCGCTGCAAGCAGCTGATCTGTGATCCCAGTTACATC

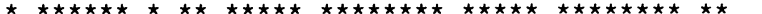

288 LysAspArgValGluLysValGlyGlnValI leArgVal IleCysIleLeu AAAGATCGAGTAGAAAAAGTGGGCCAGGTGATCAGAGTCATCTGTATTCT 911 CCAGACCGTGTGCAAAAGGCTGGCCAGGTTATTCGCATCATCTGTATCCT

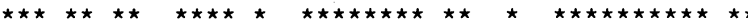

305 SerHisProIleLysAsnThrAsnAspalaAsnSerCysGlnIleIle CAGCCACCCCATCAAAAACACCAATGACGCCAACTCCTGCCAGATCATTA 961 CAGCCACCCCATCAAGAATACCAATGATGCCAATTCCTGCCAAATTATCA

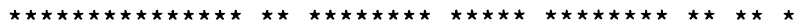

321 I leProGlnAsnGInValAsnArgLysSerAspIleTyrValCysMet I le TTCCACAGAACCAAGTCAACCGGAAGTCAGATATCTACGTCTGCATGATC 1011 TCCCTCAGAACCAGGTCAACAGGAAGTCAGACATCTATGTGTGCATGATC

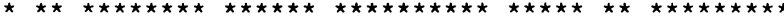

338 SerSerAlaHisAsnValAlaAlaGlnGlyLysTyrIleAlaIleAlaSer TCCTCTGCACACAATGTGGCCGCACAAGGCAAGTACATCGCCATTGCCAG 1061 TCCTATGCGCACAACGTGGCCGCACAGGGCAAATACATCGCCATTGCCAG

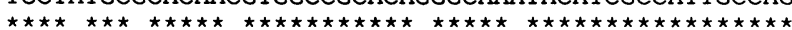

355 ThrThrValGluThrLysGluProGluLysGIuIleArgProAlaLeu CACAACGGTGGAGACCAAGGAGCCCGAGAAGGAAATCAGACCAGCCCTGG 111 CACCACTGTAGAGACTGCAGAACCAGAAAAGGAAGTTGAGCCTGCATTGG

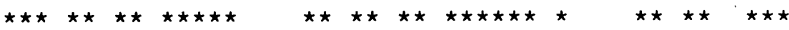

371 GIuLeuLeuGIuProIleGIuGInLysPheValSerIleSerAspLeuLeu AGCTTTTGGAACCAATTGAGCAGAAATTCGTTAGCATCAGTGACCTCCTT 1161 AGCTGTTGGAACCCATTGACCAGAAGTTTGTGGCTATCAGTGATTTATAT

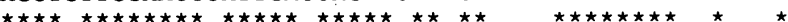

388 ValProLysAspLeuGlyThrGluSerGInIlePheIleSerArgThrTyr GTACCAAAAGACTTGGGAACAGAAAGCCAGATCTTTATATCCCGTACCTA 1211 GAGCCCATTGATGATGGTTCAGAGAGTCAGGTGTTCTGTTCCTGCTCCTA

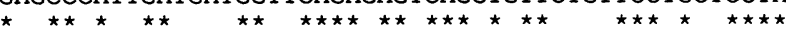

405 AspAlaThrThrHisPheGluThrThrCysAspAspIleLysAspIle TGATGCAACAACTCACTTTGAGACGACCTGTGATGACATTAAGGACATCT 1261 TGATGCTACCACACACTTTGAGACAACCTGCAATGACATCAAAGATATCT

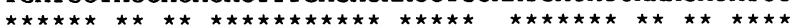

421 TyrLysArgMetMetGlySerGluPheAspPheGluGluMet LysArgLys ATAAGAGGATGATGGGATCCGAGTTTGACTTTGAGGAAATGAAGCGCAAG 1311 ACAAACGCATGGCTGGTTCTGCCTTTGATTTTGAGAACATGAAGCGCAAA

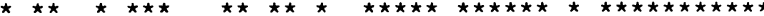

438 LysAsnAspIleTyrGIyGluGlu* * * AAAAATGACATCTATGGGGAAGAGTAACAGCAGTACATGTTATCATCTAA 1361 CAGAATGATGTCTTTGGAGAAGCTGATCAGTGATTGCTGACTCCCCTCCT

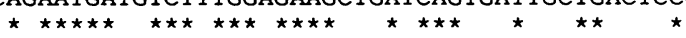
TTAGGACAAACTTAAAATTTGGCAAATGATGCATATTGTATGAAATCAGT 1411 CCAGCCCCTGTTCCCCTCTCCCCAACTTGTATGTCCTTCTCTAGGGCAGG ATTGTAAGGCCTGCTTTTGTAATCAAA GGAGATGGTATGGCTAGGCATCCTTGT 


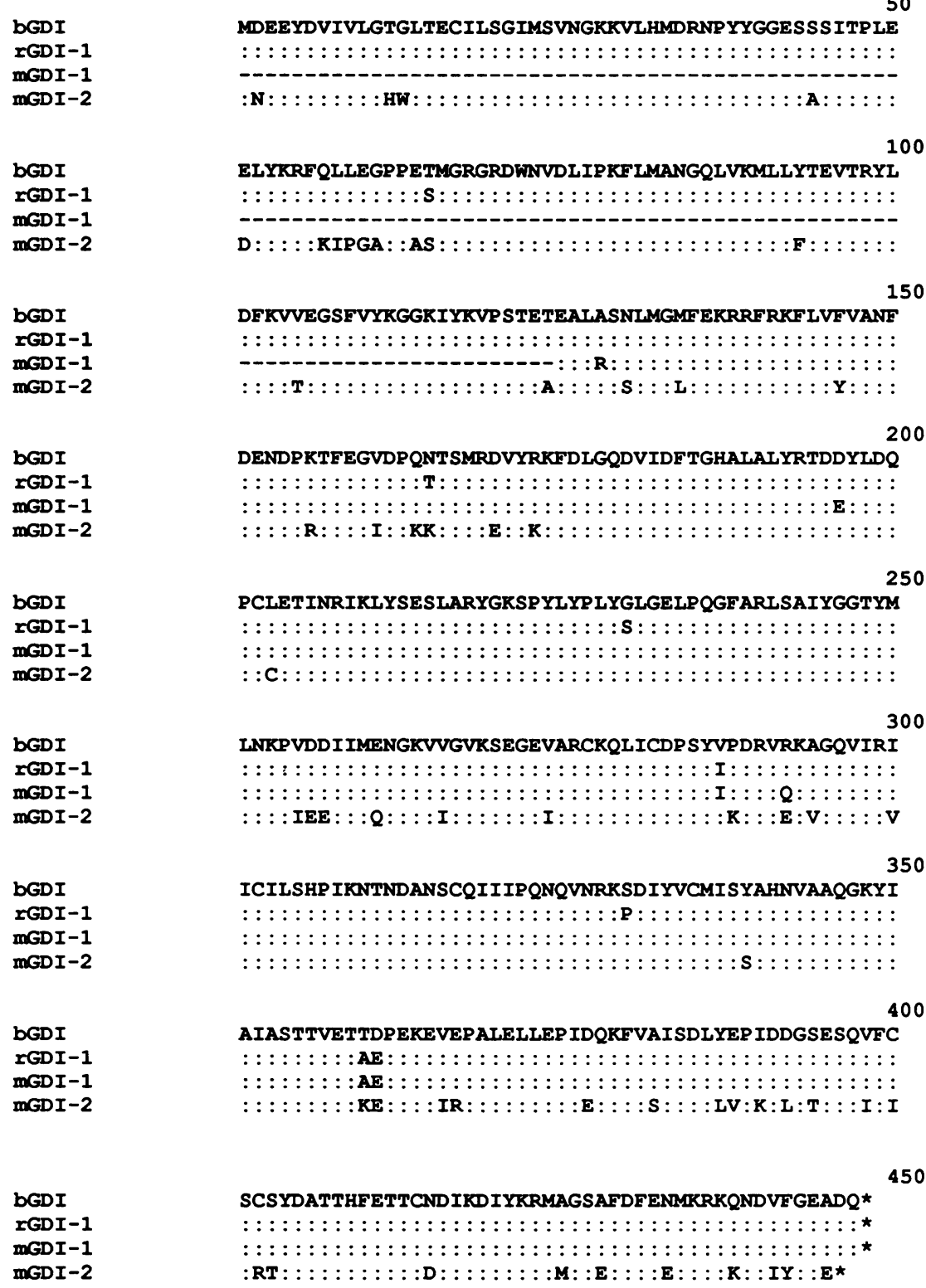

FIG. 2. Alignments of deduced amino acid sequences of bovine brain $s m g$ p25A GDI (bGDI) (19), rat brain GDI-1, and mouse skeletal muscle GDI-1 and GDI-2. Identical residues are denoted by colons, and replacements are indicated by the corresponding residue (one-letter code). The missing first 124 amino acids of mGDI-1 are marked by dashes.

ATG (TAG, nucleotides -60 to -58 ) supports the concept that this codon represents the translation initiator of the GDI-2 gene product. The nucleotide sequence of the coding region of the mGDI- 2 cDNA is $72 \%$ identical to the bovine brain smg p25A GDI (19) (Fig. 1).

Among the other clones isolated in this study was a $1.3-\mathrm{kbp}$ clone found to contain an open reading frame encoding 969 nucleotides and ending in a TGA stop codon, followed by approximately 300 nucleotides in the $3^{\prime}$ noncoding region (Fig. 1). The nucleotide sequence of the coding region of this cDNA clone, designated mGDI-1, is $90 \%$ identical to that for the bovine brain smg p25A GDI. However, this cDNA for mGDI-1 lacked the first 372 nucleotides of the predicted ATG translation start site of the smg p25A GDI. Nevertheless, the high degree of homology between mGDI-1 and the bovine GDI indicates that we have cloned a bovine brain smg p25A GDI homolog from the mouse muscle library.

The comparison of the nucleotide sequences of mGDI-1 and mGDI-2 presented in Fig. 1 suggests that these cDNA isolates are derived from different genes. Differences in the two sequences are distributed randomly along the entire cDNA coding regions. Furthermore, the $3^{\prime}$ noncoding regions are distinct sequences. These findings and the fact that the two cDNA clones were obtained from the same mouse muscle cDNA library indicate that they encode two GDI protein isoforms.

Figure 2 compares the deduced amino acid sequences of the two isolated mouse muscle GDI cDNAs with that of the bovine smg p25A GDI and rGDI-1. The overall sequence identity between mGDI-2 and mGDI-1, mGDI-2 and smg p25A GDI, 
GDI-1 GDI-2

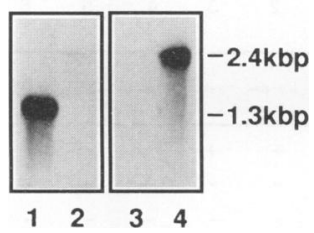

FIG. 3. Southern blot analysis of mGDI-1 and mGDI-2 cDNA inserts for estimation of cross-hybridization. Equal amounts $(\sim 0.1 \mathrm{ng})$ of the cloned mGDI-1 (1.3 kbp, lanes 1 and 3$)$ and mGDI-2 (2.4 kbp, lanes 2 and 4) cDNA inserts were electrophoresed on a 1\% agarose gel, transferred to nitrocellulose, and hybridized sequentially with the same radiolabeled cDNA inserts under high-stringency conditions. Lanes 1 and 2, radiolabeled mGDI- 1 as a probe; lanes 3 and 4, radiolabeled $\mathrm{mGDI}-2$ as a probe.

and mGDI-2 and rGDI- 1 is $85.7,86.7$, and $86.1 \%$, respectively. When conservative substitutions are eliminated, the sequence similarities are $93.5,93.8$, and $93.1 \%$, respectively. The degree of sequence identity between mGDI-1 and smg p25A GDI and between mGDI-1 and rGDI-1 is $98.1 \%$ in both cases. Interestingly, many of the nonconservative substitutions between mGDI- 1 and mGDI- 2 are concentrated in the C-terminal region of the proteins.

Northern blot analysis of various tissues and insulinresponsive cells. Previous studies have shown that smg p25A GDI message is predominantly expressed in rat brain, although it was also found in all other tissues tested (19). To analyze whether the newly discovered mGDI-2 is specific for muscle, we attempted to perform Northern blot analysis of various human tissues. Since both GDI forms were found to recognize mRNA transcripts of similar size $(2.4 \mathrm{~kb})$, pilot experiments were performed to determine the conditions that eliminate cross-hybridization. Figure 3 shows that under hybridization conditions of relatively high stringency, this could be achieved by using the radiolabeled $1.3-\mathrm{kbp} \mathrm{mGDI}-1$ and $2.4-\mathrm{kbp}$ mGDI-2 cDNA isolates as probes. These conditions were thus used for the Northern blot analysis.

Northern blots of mRNA prepared from various human tissues probed with radiolabeled mGDI- 1 and mGDI- 2 cDNAs are depicted in Fig. 4. This analysis revealed that GDI-2 mRNA was highly abundant not only in skeletal muscle but also in lung (highest level), brain, and placenta. To a lesser extent, the GDI-2 transcript was also detected in the other tissues investigated, including heart, kidney, pancreas, and liver. Brain, skeletal muscle, placenta, and liver also expressed

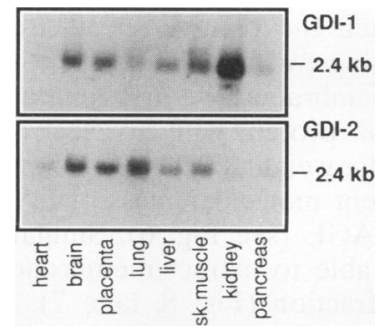

FIG. 4. Northern blot analysis of GDI-1 and GDI-2 mRNA levels in various human tissues. Each lane contained $1 \mu \mathrm{g}$ of poly(A) ${ }^{+}$RNA. The same blot was hybridized sequentially with the radiolabeled mGDI-1 (1.3 kbp) cDNA cloned in these studies and with the full-length mGDI-2 cDNA insert $(2.4 \mathrm{kbp})$ under high-stringency conditions. sk, skeletal.

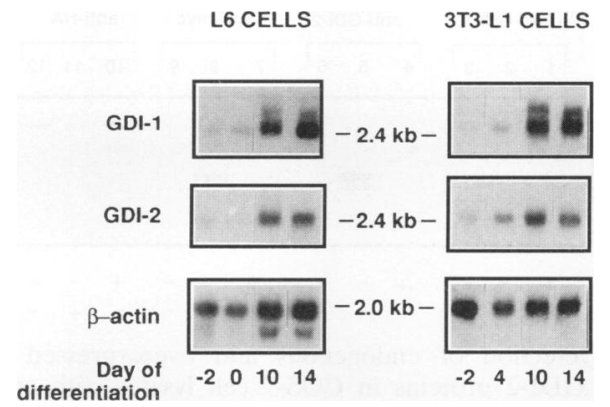

FIG. 5. Northern blot analysis of GDI-1, GDI-2, and $\beta$-actin transcript levels during differentiation of L6 myoblasts and 3T3-L1 fibroblasts. Each lane was loaded with $3 \mu \mathrm{g}$ of poly $(\mathrm{A})^{+}$RNA isolated from L6 and 3T3-L1 cells on the indicated day of the differentiation program. The same blots were hybridized sequentially with the radiolabeled mGDI-1 (1.3 kbp), mGDI-2 insert $(2.4 \mathrm{kbp})$, and $\beta$-actin probes under high-stringency conditions. A representative experiment from three independent differentiations of each cell line is shown.

GDI-1 mRNA at levels apparently similar to those of GDI-2. In contrast, kidney expressed predominantly GDI-1 mRNA, while in human lung tissue, GDI-2 was the predominant transcript present (Fig. 4).

The level of GDI-1 and GDI-2 mRNA species present in 3T3-L1 mouse cells and L6 rat cells was also determined by Northern blot analysis. The cultured cell lines differentiate from relatively insulin-unresponsive fibroblasts to highly insulin-sensitive adipocytes and myocytes, respectively. After differentiation, these cells express the GLUT4 glucose transporter protein and exhibit insulin-mediated GLUT4 redistribution to the cell surface membrane (9). Both GDI-1 and GDI-2 transcripts were observed upon Northern blot analysis of mRNA derived from L6 and 3T3-L1 fibroblasts (Fig. 5). After differentiation, the levels of both GDI-1 and GDI-2 mRNA species increased relative to the level of $\beta$-actin mRNA present (7-fold and 3-fold, respectively, in L6 myocytes; 10-fold and 5-fold, respectively, in 3T3-L1 adipocytes) (Fig. 5). These data suggest that significant amounts of both GDI protein isoforms exist in these cell lines and that the amounts of these proteins increase in the fully differentiated, insulin-responsive state.

Detection of endogenous and epitope-tagged GDI-1 and GDI-2 proteins. In order to detect GDI proteins, we developed specific antibodies against unique peptide sequences in mGDI-1 and mGDI-2. Anti-GDI-1 antibodies were directed against residues 431 to 447 in the $C$ terminus of mGDI- 1 and recognized a major endogenous protein in COS-7 cell lysates that appeared on SDS-PAGE as an apparent 55-kDa protein band (Fig. 6, lane 3). Transient expression of the HA epitopetagged rGDI-1 in some cells resulted in the appearance of a $57-\mathrm{kDa}$ band in a similar analysis (Fig. 6, lane 1). The anti-GDI-1 peptide antiserum did not cross-react with the endogenous GDI-2 but did recognize the higher amounts of protein obtained by transiently overexpressing a c-Myc-tagged mGDI-2 construct (apparent 48-kDa band, Fig. 6, lane 2). Anti-GDI-2 antibodies directed against a peptide sequence that is divergent between the two isoforms (residues 386 to 404 in the C-terminal region) detected a protein with an apparent molecular mass of $46 \mathrm{kDa}$ that migrated slightly faster than the overexpressed c-Myc-mGDI-2 (Fig. 6, lane 5). Neither the endogenous nor the expressed epitope-tagged rGDI-1 isoform was detected by anti-GDI-2 antibodies (Fig. 6, lanes 4 and 5). It is interesting that although both forms of GDI have deduced 


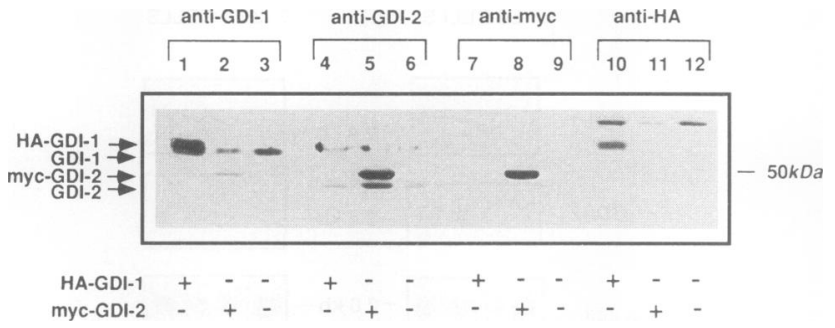

FIG. 6. Detection of endogenous and overexpressed forms of GDI-1 and GDI-2 proteins in COS-7 cell lysates with anti-GDI-1, anti-GDI-2, anti-HA, and anti-c-Myc antibodies. COS-7 cells transiently transfected or not with HA-rGDI-1 or c-Myc-mGDI-2 were lysed in $50 \mathrm{mM}$ HEPES buffer ( $\mathrm{pH} 7.5$ ) containing $150 \mathrm{mM} \mathrm{NaCl}, 1$ mM PMSF, $0.1 \%$ SDS, $0.5 \%$ sodium deoxycholate, and $1 \%$ Nonidet P-40 and fractionated by SDS-10.5\% PAGE. The electrophoresed proteins were transferred to nitrocellulose and immunoblotted with anti-GDI-1 peptide antiserum (1:14,000), anti-GDI-2 peptide antiserum $(1: 14,000)$, anti-c-Myc monoclonal antibody (1:500; ATCC $1729)$, and anti-HA monoclonal antibody $(1: 1,000 ; 12 \mathrm{CA} 5)$, as indicated.

molecular weights of about 51,000 , the apparent molecular masses determined by SDS-PAGE are 55 and $46 \mathrm{kDa}$ for GDI-1 and GDI-2, respectively.

The specific anti-GDI-1 and anti-GDI-2 antisera described above were used to test whether increased GDI protein levels are associated with 3T3-L1 cell differentiation, as suggested by the data shown in Fig. 5. Cytosolic fractions obtained from cultured 3T3-L1 fibroblasts and differentiated 3T3-L1 adipocytes were analyzed by SDS-PAGE and Western blotting with the antisera. As depicted in Fig. 7, the concentrations of immunoreactive mGDI-1 and mGDI-2 proteins were elevated approximately nine- and threefold, respectively, in the cultured adipocytes compared with their levels in fibroblasts. These data indicate that the acquired insulin sensitivity of 3T3-L1 adipocytes is associated with marked increases in GDI protein levels. Further data will be required to determine whether these or other GDI proteins play a direct role in the altered membrane trafficking of glucose transporters in response to insulin in these cells.

GST-GDI-2 modulates membrane association of Rab proteins. Several studies have demonstrated that bovine brain GDI releases membrane-associated Rab proteins $(25,34,38)$.

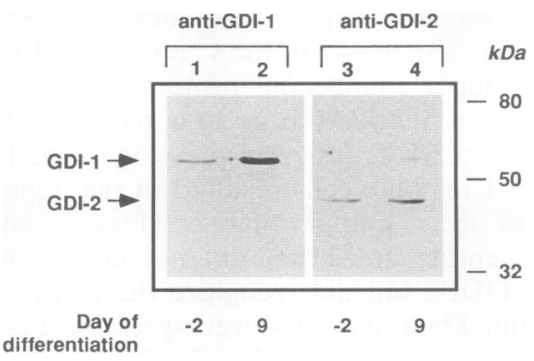

FIG. 7. Western blot analysis of protein levels of mGDI-1 and mGDI-2 during differentiation of 3T3-L1 cells. Each lane was loaded with $20 \mu \mathrm{g}$ of cytosolic protein, obtained by homogenization $(20 \mathrm{mM}$ HEPES buffer [pH 7.4] containing $1 \mathrm{mM}$ EDTA, $250 \mathrm{mM}$ sucrose, and protease inhibitors) and centrifugation $(200,000 \times g$ for $15 \mathrm{~min}$ in a Beckman TL-100 Ultracentrifuge) of 3T3-L1 cells on the indicated day of the differentiation schedule. The proteins were analyzed by SDSPAGE, transferred to nitrocellulose, and immunoblotted with antiGDI-1 or anti-GDI-2 peptide antisera as indicated.

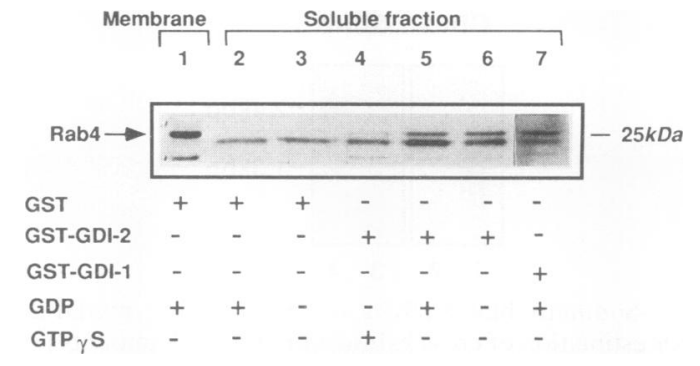

FIG. 8. GST-GDI-2 and GST-GDI-1 release membrane-bound Rab4. Postnuclear membranes of COS-7 cells were incubated for 45 min at $30^{\circ} \mathrm{C}$ with or without GDP or GTP $\gamma \mathrm{S}$ (each at $1 \mathrm{mM}$ ) as indicated. The incubation was prolonged for an additional $30 \mathrm{~min}$ at $30^{\circ} \mathrm{C}$ in the presence or absence of GST alone, GST-GDI-1, or GST-GDI-2 (each at $1 \mu \mathrm{M})$. The reaction mixtures were then centrifuged, and the membrane and soluble fractions were analyzed for their Rab4 content by SDS-PAGE and immunoblotting with affinity-purified polyclonal anti-Rab4 antibodies. The position of Rab4, as determined from the membrane fraction, is denoted by an arrow. The second band detected in the soluble fraction is nonspecific. A representative experiment from three independent membrane preparations is shown.

The close similarity between the sequences of mGDI-1 and mGDI-2 indicates that the novel isoform may fulfill similar functions. To address this question, we first generated a recombinant GST-GDI-2 fusion protein. The electrophoretic mobility of this expressed fusion protein (molecular weight, 75,000 ; not shown) corresponded well to the apparent molecular mass of GST plus mGDI-2 as determined by SDS-PAGE (see Fig. 6).

The ability of GST-GDI-2 to remove Rab4 protein from membranes was assessed. As shown in Fig. 8, immunoreactive Rab4 is associated with isolated membranes of COS-7 cells (lane 1) and is not detected in the soluble fractions after incubating cell membranes with GST (lanes 2 and 3). In contrast, after incubation of membranes with the recombinant GST-GDI-2 protein $(1 \mu \mathrm{M})$, Rab4 was readily detected in the soluble fraction (Fig. 8, lane 6). GDP (1 mM) only slightly augmented this membrane dissociation of Rab4, while GTP $\gamma \mathrm{S}$ abrogated it (Fig. 8, lanes 4 and 5). Since Rab4 in membranes is presumably already in the GDP-bound form, this result indicates that, similar to bovine brain GDI, GDI-2 binds to the GDP-bound form of the Rab protein in membranes and releases it into the soluble fraction. Under the conditions used in these experiments, the capacity of our GST-GDI-2 fusion protein at $1 \mu \mathrm{M}$ to solubilize Rab4 amounted to $\sim 15$ to $20 \%$ of the total membrane-associated Rab4 (Fig. 6, lane 5 versus lane 1).

We next assessed the relative specificities of GDI-2 and GDI-1 for extracting two members of the Rab family, Rab4 and Rab5, from membranes. We first generated a recombinant GST-GDI-1 fusion protein with an electrophoretic mobility (apparent molecular weight, 80,000; not shown) corresponding well to the apparent molecular mass of GST plus GDI-1, as judged by SDS-PAGE (see Fig. 6). Similar to GST-GDI-2, GST-GDI-1 was able to extract membrane-associated Rab4 into the soluble fraction (Fig. 8, lane 7). GST-GDI-1 at a concentration of $1 \mu \mathrm{M}$ solubilized an amount of total membrane-associated Rab4 similar to that solubilized by GSTGDI-2 in three separate experiments.

The ability of both fusion proteins to dissociate membranebound Rab5 was also compared. As shown in Fig. 9, both recombinant GDI isoforms were able to solubilize immunore- 


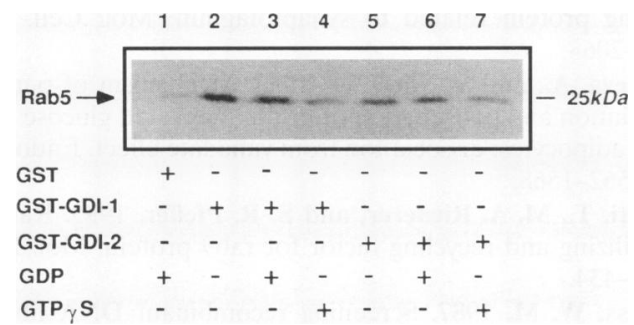

FIG. 9. GST-GDI-1 and GST-GDI-2 release membrane-bound Rab5. Postnuclear membranes of COS-7 cells were incubated (45 min, $30^{\circ} \mathrm{C}$ ) with or without GDP or GTP $\gamma \mathrm{S}$ (each at $1 \mathrm{mM}$ ) as indicated. The incubation was prolonged for an additional $30 \mathrm{~min}$ at $30^{\circ} \mathrm{C}$ in the presence or absence of GST alone, GST-GDI-1, or GST-GDI-2 (each at $1 \mu \mathrm{M})$. The reaction mixtures were pelleted, and the soluble fractions were analyzed for their Rab5 content by SDS-PAGE and immunoblotting with affinity-purified monoclonal anti-Rab5 antibodies.

active Rab5 when incubated with COS-7 cell membranes (lanes 2 and 5). This effect was inhibited by GTP $\gamma$ S (Fig. 9, lanes 4 and 7) and only slightly enhanced by GDP, probably because of the predominance of GDP-bound Rab5 already present in the membranes. These data suggest that both rGDI-1 and mGDI-2 can function as regulatory proteins for Rab4 and Rab5. However, we cannot conclude from these experiments that subtle differences in the regulation of Rab4 and Rab5 proteins by GDI-1 versus GDI-2 are not also physiologically important.

An important extension of the above experiments will be to test the possibility that one or more of the other Rab proteins are uniquely regulated by only one of the two GDI isoforms studied here. This important question will be challenging to address because of the large number of unique Rab protein candidates to be screened. There is precedence for such specificity. The purified form of the GDI for Rab11 does not interact with Rab3A (37). The significant variations in the amino acid sequences of GDI-1 and GDI-2, especially in the C-terminal region, could serve as the basis for Rab-binding specificity. However, other properties could also differ between the two proteins, such as cellular localization, regulated phosphorylation, or other posttranslational modifications.

In summary, we have identified and characterized a novel isoform of mammalian GDI that releases membrane-bound Rab4 and Rab5 proteins and is widely expressed in primary tissues and in insulin-responsive cultured cells. Thus, at least two gene products in murine tissues carry out the functions of GDI proteins in regulating membrane trafficking. It will be of interest to determine whether important differences in function characterize the two GDI isoforms described here. The cloning of the cDNA encoding the novel GDI-2 protein should facilitate efforts to answer this question.

\section{ACKNOWLEDGMENTS}

We thank Judy Kula for excellent assistance in preparation of the manuscript and Andrew Cherniack, Herman Meisner, Anil Chawla, and Joanne Buxton for valuable discussions and technical advice. The generous gifts of anti-Rab4 antibodies by Ira Mellman and anti-Rab5 antibodies by Marino Zerial are very much appreciated.

This work was supported by grant DK30898 from the National Institutes of Health.

\section{REFERENCES}

1. Balch, W. E. 1990. Small GTP-binding proteins in vesicular transport. Trends Biochem. Sci. 15:473-476.
2. Baldini, G., T. Hohl, H. Y. Lin, and H. F. Lodish. 1992. Cloning of a Rab3 isotype predominantly expressed in adipocytes. Proc. Natl. Acad. Sci. USA 89:5049-5052.

3. Becker, J., T. J. Tan, H.-H. Trepte, and D. Gallwitz. 1991. Mutational analysis of the putative effector domain of the GTPbinding Ypt 1 protein in yeast suggests specific regulation by a novel GAP activity. EMBO J. 10:785-792.

4. Burstein, E. S., K. Linko-Stentz, Z. Lu, and I. G. Macara. 1991. Regulation of the GTPase activity of the ras-like protein p25 ${ }^{\text {rab3A }}$. J. Biol. Chem. 266:2689-2692.

5. Burstein, E. S., and I. G. Macara. 1992. Characterization of a guanine nucleotide-releasing factor and a GTPase-activating protein that are specific for the ras-related protein p25 rab3A. Proc. Natl. Acad. Sci. USA 89:1154-1158.

6. Chomczynski, P., and N. Sacchi. 1987. Single-step method of RNA isolation by acid guanidinium thiocyanate-phenol-chloroform extraction. Anal. Biochem. 162:156-159.

7. Cormont, M., J.-F. Tanti, A. Zahraoui, E. Van Obberghen, A. Tavitian, and Y. Le Marchand-Brustel. 1993. Insulin and okadaic acid induce Rab4 redistribution in adipocytes. J. Biol. Chem. 268:19491-19497.

8. Czech, M. P., and J. M. Buxton. 1993. Insulin action on the internalization of the GLUT4 glucose transporter in isolated rat adipocytes. J. Biol. Chem. 268:9187-9190.

9. Czech, M. P., B. M. Clancy, A. Pessino, C.-W. Woon, and S. A. Harrison. 1992. Complex regulation of simple sugar transport in insulin-responsive cells. Trends Biochem. Sci. 17:197-200.

10. Feinberg, A. P., and B. Vogelstein. 1983. A technique for radiolabeling DNA restriction endonuclease fragments to high specific activity. Anal. Biochem. 132:6-13.

11. Field, J., J.-I. Nikawa, D. Broek, B. MacDonald, L. Rodgers, I. A. Wilson, R. A. Lerner, and M. Wigler. 1988. Purification of a $R A S$-responsive adenylyl cyclase complex from Saccharomyces cerevisiae by use of an epitope addition method. Mol. Cell. Biol. 8:2159-2165.

12. Gorman, C. 1985 . High efficiency gene transfer into mammalian cells, p. 143-190. In D. M. Glover (ed.), DNA cloning, vol. II. IRL Press, Oxford.

13. Gorvel, J. P., P. Chavrier, M. Zerial, and J. Gruenberg. 1991. Rab5 controls early endosome fusion in vitro. Cell 64:915-925.

14. Harrison, S. A., J. M. Buxton, B. M. Clancy, and M. P. Czech. 1990. Insulin regulation of hexose transport in mouse 3T3-LL cells expressing the human HepG2 glucose transporter. J. Biol. Chem. 265:20106-20116.

15. Higgins, D. G., A. J. Bleasby, and R. Fuchs. 1992. CLUSTAL V: improved software for multiple sequence alignment. Comput. Appl. Biosci. 8:189-191.

16. Jhun, B. H., A. L. Rampal, H. Liu, M. Lachaal, and C. Y. Jung. 1992. Effects of insulin on steady state kinetics of GLUT4 subcellular distribution in rat adipocytes. J. Biol. Chem. 267:1771017715.

17. Kozak, M. 1987. An analysis of 5'-noncoding sequences from 699 vertebrate messenger RNAs. Nucleic Acids Res. 15:8125-8148.

18. Liedo, P.-M., P. Vernier, J.-D. Vincent, W. T. Mason, and R. Zorec. 1993. Inhibition of Rab3B expression attenuates $\mathrm{Ca}^{2+}$-dependent exocytosis in rat anterior pituitary cells. Nature (London) 364:540544.

19. Matsui, Y., A. Kikuchi, S. Araki, Y. Hata, J. Kondo, Y. Teranishi, and Y. Takai. 1990. Molecular cloning and characterization of a novel type of regulatory protein (GDI) for $s m g$ p25A, a ras p21-like GTP-binding protein. Mol. Cell. Biol. 10:4116-4122.

20. Moya, M., D. Roberts, and P. Novick. 1993. DSS4- 1 is a dominant suppressor of sec $4-8$ that encodes a nucleotide exchange protein that aids Sec4p function. Nature (London) 361:460-463.

21. Munro, S., and H. R. B. Pelham. 1988. An Hsp70-like protein in the ER: identity with the $78 \mathrm{kd}$ glucose-regulated protein and immunoglobulin heavy chain binding protein. Cell 48:291-300.

22. Nonaka, H., K. Kaibuchi, K. Shimizu, J. Yamamoto, and Y. Takai. 1991. Tissue and subcellular distributions of an inhibitory GDP/ GTP exchange protein (GDI) for smg p25A by use of its antibody. Biochem. Biophys. Res. Commun. 174:556-563.

23. Pfeffer, S. R. 1992. GTP-binding proteins in intracellular transport. Trends Cell Biol. 2:41-46. 
24. Plutner, H., A. D. Cox, S. Pind, R. Khosravi-Far, J. R. Bourne, R. Schwaninger, C. J. Der, and W. E. Balch. 1991. Rab1b regulates vesicular transport between the endoplasmic reticulum and successive Golgi compartments. J. Cell Biol. 115:31-43.

25. Regazzi, R., A. Kikuchi, Y. Takai, and C. B. Wollheim. 1992. The small GTP-binding proteins in the cytosol of insulin-secreting cells are complexed to GDP dissociation inhibitor proteins. J. Biol. Chem. 267:17512-17519.

26. Rexach, M. F., and R. W. Schekman. 1991. Distinct biochemical requirements for the budding, targeting and fusion of ER-derived transport vesicles. J. Cell Biol. 114:219-229.

27. Salminen, A., and P. J. Novick. 1987. A ras-like protein is required for a post-Golgi event in yeast secretion. Cell 49:527-538.

28. Sanger, F., S. Nicklen, and A. R. Coulson. 1977. DNA sequencing with chain-terminating inhibitors. Proc. Natl. Acad. Sci. USA 74:5463-5467.

29. Sasaki, T., K. Kaibuchi, A. K. Kabcenell, P. J. Novick, and Y. Takai. 1991. A mammalian inhibitory GDP/GTP exchange protein (GDP dissociation inhibitor) for smg p25A is active on the yeast SEC4 protein. Mol. Cell. Biol. 11:2909-2912.

30. Sasaki, T., A. Kikuchi, S. Araki, Y. Hata, M. Isomura, S. Kuroda, and Y. Takai. 1990. Purification and characterization from bovine brain cytosol of a protein that inhibits the dissociation of GDP from and the subsequent binding of GTP to smg p25A, a ras p21-like GTP-binding protein. J. Biol. Chem. 265:2333-2337.

31. Segev, N. 1991. Mediation of the attachment or fusion step in vesicular transport by the GTP-binding Ypt1 protein. Science 252:1553-1556.

32. Shirataki, H., K. Kaibuchi, T. Sakoda, S. Kishida, T. Yamaguchi, K. Wada, M. Miyazaki, and Y. Takai. 1993. Rabphilin-3A, a putative target protein for smg p25A/rab3A p25 small GTP- binding protein related to synaptotagmin. Mol. Cell. Biol. 13: 2061-2068.

33. Shisheva, A., and Y. Shechter. 1993. Mechanism of pervanadate stimulation and potentiation of insulin-activated glucose transport in rat adipocytes: dissociation from vanadate effect. Endocrinology 133:1562-1568.

34. Soldati, T., M. A. Riederer, and S. R. Pfeffer. 1993. Rab GDI: a solubilizing and recycling factor for rab9 protein. Mol. Biol. Cell 4:425-434.

35. Strauss, W. M. 1987. Screening recombinant DNA libraries, p. 6.0.1-6.3.6. In F. M. Ausubel, R. Brent, R. E. Kingston, D. D. Moore, J. G. Seidman, J. A. Smith, and K. Struhl (ed.), Current protocols in molecular biology. Wiley-Interscience, New York.

36. Takai, Y., K. Kaibuchi, A. Kikuchi, and M. Kawata. 1992. Small GTP-binding proteins. Int. Rev. Cytol. 133:187-230.

37. Ueda, T., Y. Takeyama, T. Ohmori, H. Ohyanagi, Y. Saitoh, and Y. Takai. 1991. Purification and characterization from rat liver cytosol of a GDP dissociation inhibitor (GDI) for liver $24 \mathrm{~K} \mathrm{G}$, a ras $\mathrm{p} 21$-like GTP-binding protein, with properties similar to those of smg p25A GDI. Biochemistry 30:909-917.

38. Ullrich, O., H. Stenmark, K. Alexandrov, L. A. Huber, K. Kaibuchi, T. Sasaki, Y. Takai, and M. Zerial. 1993. Rab GDP dissociation inhibitor as a general regulator for the membrane association of Rab proteins. J. Biol. Chem. 268:18143-18150.

39. Ushkaryov, Y., and T. Südhof. 1993. Neurexin III $\alpha$ : extensive alternative splicing generates membrane-bound and soluble forms. Proc. Natl. Acad. Sci. USA 90:6410-6414.

40. Yang, J., and G. D. Holman. 1993. Comparison of GLUT4 and GLUT1 subcellular trafficking in basal and insulin-stimulated 3T3-L1 cells. J. Biol. Chem. 268:4600-4603. 